\title{
SYSTEMATIC REVIEW OF THE LITERATURE ON SUPPLIER CODE OF CONDUCT
}

\author{
Monika Jedynak*
}

\begin{abstract}
Background. Cooperation with suppliers has an important bearing on the organisation's ability to achieve its objectives. The supplier selection processes include various criteria which increasingly have also other than purely economic interest. Supplier code of conduct is one of tools for shaping relations between organisations and their suppliers which, applied mostly on international markets, expand dimensions of requirements suppliers should meet. The article analyses degree and scope of presence of supplier code of conduct in reviewed scientific publications.
\end{abstract}

Research aims. Aim of the research is to identify presence of the issue of supplier code of conduct in reviewed scientific journals. The following research questions have been raised: 1 . is there a research gap in the field of supplier code of conduct?; 2. which scientific journals publish articles on supplier code of conduct?; 3 . which research areas undertake the subject of supplier code of conduct?

Methodology. Systematic literature review was the fundamental research method. Papers subject to analysis were selected based on EBSCO and ProQuest.

Key findings. Bibliometric and contextual analysis have led to the formulation of the following conclusions: 1 . the issue of supplier code of conduct is present in reviewed scientific publications only to a very limited degree, 2 . scientific journals publishing articles of supplier code of conduct have diversified profiles, 3. supplier code of conduct is a research subject in numerous research areas. Consequently to the systematic literature review proposals for future research directions have been drawn up.

Keywords: suppliers, code of conduct, systematic literature review.

* Jagiellonian University, Institute of Economics, Finance and Management. E-mail: monika.jedynak@uj.edu.pl 


\section{INTRODUCTION}

The subject of cooperation between organisations and suppliers is present in a number of scientific publications ${ }^{1}$, and is a matter of interest also to practitioners. This issue is currently raised in literature as part of such areas as (Bai \& Sarkis, 2010): suppliers management, supplier relationship, supplier cooperation, supplier selection, and supply chain management. While in practice it is a subject of advisory services offered by as renowned entities as Deloitte or PWC, which only proves the importance of relationships with suppliers in business models of organisations. Advisory companies provide their customers in this case with framework models of conduct.

The large number of publications on cooperation with suppliers does not mean however that all research problems are equally represented. Bearing in mind the current, numerous initiatives aiming at drawing entrepreneurs' attention to include in their operations aspects other than financial, e.g. environmental or social (in line with the CSR concept), it seems interesting to ask if research issues related to these themes are also raised. In case of cooperation with suppliers, the subject of supplier codes of conduct appears to deserve analysis as it potentially expresses management strategy aimed at selection and development of suppliers including norms and values representing broader than purely financial sensitivity of organization.

\section{THE IDEA OF SUPPLIER CODE OF CONDUCT}

Together, with the development of globalisation, international outlets opened, while goods and services became available all over the world. International corporations started to locate their manufacturing processes in countries where the labour costs are low. It resulted in problems not existing before on such a scale, e.g. labour exploitation, child

${ }^{1}$ E.g. when searching the EBSCO data base by the word "suppliers" and marking search options as Full Text and Peer Reviewed there are 17838 results; https://extranet.uj.edu.pl/ eds/,DanaInfo=eds.b.ebscohost.com+resultsadvanced?vid=21\&sid=e31af0c4-48e4-4205-bba 3 -c9d15d75549f\%40sessionmgr103\&bquery $=\mathrm{TI}+$ suppliers\&bdata=JmNsaTA9RlQmY2x2MD1ZJmNsaTE9UIYmY2x2MT1ZJmNsaTI9RFQxJmNsdjI9MjAwNTAxLTIwMTgxMiZ0eXBlPTEmc210ZT11ZHMtbGl2ZQ\%3d\%3d (accessed: 18 $8^{\text {th }}$ Oct 2018). 
labour, or environmental pollution. This phenomenon was addressed by strong engagement of international organisations, governments, and non-government organisations in developing international codes of conduct including guidelines for compliance with standards and values in running a business.

During the $1990 \mathrm{~s}$, multinational corporations started to acknowledge responsibility for working conditions at their suppliers factories in developing countries, and codes of conduct emerged as the dominant way to operationalise this extended sense of responsibility (Egels-Zandén \& Hyllman, 2007; Kolk \& van Tulder, 2002b; Radin, 2004; Sethi, 2002).

In general, corporate codes of conduct are written statements of principle or policy serving as the expression of a commitment to particular enterprise conduct (Diller, 1999; Kolk \& van Tulder, 2002a). In the field of Corporate Social Responsibility (CSR), one efficient way to improve the ethical behaviour of a company is the implementation of a code of conduct (Oehmen et al., 2010, p. 664).

A Code of Conduct (SCC) is a set of written principles, guidelines, or standards, which are intended to improve the company's social and environmental performance (Pedersen \& Andersen, 2006, p. 229). It is also a popular tool by which buyers manage and monitor their suppliers' ethical and socially responsible practices (Waddock et al., 2002; Roberts, 2003).

Companies are increasingly held responsible for the conditions under which their products are being produced, these codes often go well beyond the boundaries of the individual organization and include social and environmental requirements for suppliers (Roberts, 2003, p. 163; Jenkins, 2005, p. 527).

Codes of conduct have become ubiquitous in operations of international corporations and can be designed for different reasons and for different purposes (Schwartz, 2001). As Sethi shows (2002), codes of conduct can be an image-building tool for external entities without reflecting the actual identity of a company and can be merely an instrument recommending a specific way of operating without the possibility to execute the guidelines included.

The subject of supplier code of conduct is to a great extent addressed in the light of employee rights in production plants of international companies (e.g. Barrientos \& Smith, 2007; Chan \& Siu, 2010), principles for operational cooperation with suppliers, occupational health and 
safety, enforcement of provisions on child labour, humane working hours, or equitable remuneration (Jiang, 2009b).

Increasingly frequently organisations publish their requirements towards suppliers in special documents in the form of guidelines such as supplier code of conduct (Urbaniak, 2018).

Due to the fact that suppliers might have an economic incentive to reduce social and environmental standards in order to achieve financial gains (Pedersen \& Andersen, 2006, p. 230), a code of conduct may be a guarantee for buyers against suppliers' undesirable practices. It can be observed that a growing number of international corporations at the initial and interim evaluation of their suppliers takes into account criteria referring to implementing CSR activities (Kumara \& Rahman 2015). As a result, purchasers publish their requirements towards their suppliers in the form of special documents with guidelines - supplier code of conduct (Urbaniak, 2018).

\section{RESEARCH METHODOLOGY}

Literature peer review has a relatively broad scope and can be referred both to analysis of available literature using traditional approach, and to study carried out in a systematic manner with the use of electronic data bases (systematic literature review) (Orłowska et al., 2017).

The systematic literature peer review is a method which enables to search answers to the research question with the use of scientific methods of identification, evaluation, and synthesis of sources on a chosen research problem (Petticrew \& Roberts, 2006). The method facilitates identification, evaluation, and interpretation of studies in a given field in the course of analysing existing theoretical concepts or empirical studies enabling thus to carry out a research reproducibly (Rowley \& Slack, 2004; Seuring \& Müller, 2008).

Systematic literature peer review as a research method enhances better understanding of the essence of carried out research, allows to indicate direction of future studies and to identify research gap (Burgess et al., 2006). Procedure assumes use of electronic data bases which, in the digital age, is a convenient tool for analysing scientific sources (Rowley \& Slack, 2004). Furthermore, systematic literature peer review is characterised by reproducibility of results possible, due to the fact that the entire process of obtaining, evaluating and 
synthesis of literature should be precisely documented and carried out according to strictly defined standards (Tranfield, Denyer \& Smart, 2003). Correctly carried out systematic review synthesises present state of knowledge and informs about gaps in literature and needs for further studies (Mazur \& Orłowska, 2018).

As Czakon (2016, p. 124) points out, in the procedure of revision and selection of literature the following stages can be singled out: 1. specifying the research aim, 2. identification of fundamental literature, 3. selection of publications, 4. preparing publications' database, 5. bibliometric analysis, 6. content analysis, 7. drawing up a report.

The carried out systematic literature peer review on suppliers code of conduct addresses the following research questions:

1) Is there a research gap in the area of supplier code of conduct?

2) Which scientific journals publish articles on supplier code of conduct?

3) Which research areas undertake the subject of supplier code of conduct?

Table 1 presents the course of creating a literature base for research on the issue of supplier code of conduct, which is the subject of the present paper.

Table 1. Course of creating literature base for studies on the issue of "suppliers code of conduct"

\begin{tabular}{|l|c|c|}
\hline \multicolumn{1}{|c|}{ Search criteria } & ProQuest & EBSCO \\
\hline "Suppliers" - in title & 179,748 & 684 \\
\hline "Code of conduct" in abstract & 225 & 511 \\
\hline Full text peer reviewed & 19 & 43 \\
\hline After verification of titles and abstracts & 14 & 18 \\
\hline Total & \multicolumn{2}{|c|}{20} \\
\hline
\end{tabular}

Source: own study.

Literature was selected with the use of ProQuest and EBSCO databases. In the course of selecting literature the term "suppliers" was used as a criterion for search in titles, next term "code of conduct" in abstract. Later criterium was to include full texts peer reviewed. After verification of titles and abstracts, and eliminating recurring articles, a data base was created including 20 articles published 1990-2018, which became subject of further analysis. 
Such a small number of publications allows to conclude that there is a research gap in analysis of "supplier code of conduct", as a tool useful for management of relations with suppliers.

Table 2 demonstrates synthetic listing of publications singled out in the course of selection, together with authors, titles, years of publication, and received reference number in chronological order.

Table 2. Supplier code of conduct literature review sample

\begin{tabular}{|c|c|c|c|}
\hline $\begin{array}{c}\text { Reference } \\
\text { number }\end{array}$ & Author(s) & Title & Year \\
\hline$[11]$ & $\begin{array}{l}\text { Luc Huyse } \\
\text { Stephan Parmentier }\end{array}$ & $\begin{array}{l}\text { The Dialogue Between Consumers and } \\
\text { Suppliers Through Codes of Conduct in the } \\
\text { European Community }\end{array}$ & 1990 \\
\hline$[05]$ & $\begin{array}{l}\text { Esben Rahbek Ped- } \\
\text { ersen } \\
\text { Mette Andersen }\end{array}$ & $\begin{array}{l}\text { Safeguarding Corporate Social Respon- } \\
\text { sibility (CSR) in Global Supply Chains: } \\
\text { How Codes of Conduct Are Managed in } \\
\text { Buyer-supplier Relationships }\end{array}$ & 2006 \\
\hline$[06]$ & Katherine E. Kenny & $\begin{array}{l}\text { Code or Contract: Whether Wal-Mart's } \\
\text { Code of Conduct Creates a Contractual } \\
\text { Obligation Between Wal-Mart and the } \\
\text { Employees of Its Foreign Suppliers }\end{array}$ & 2007 \\
\hline$[07]$ & $\begin{array}{l}\text { Niklas Egels- } \\
\text {-Zandén }\end{array}$ & $\begin{array}{l}\text { Suppliers Compliance with MNCs Codes of } \\
\text { Conduct: Behind the Scenes at Chinese Toy } \\
\text { Suppliers }\end{array}$ & 2007 \\
\hline$[08]$ & Xiaomin Yu & $\begin{array}{l}\text { Impacts of Corporate Code of Conduct on } \\
\text { Labor Standards: A Case Study of Reebok's } \\
\text { Athletic Footwear Supplier Factory in } \\
\text { China }\end{array}$ & 2007 \\
\hline [09] & $\begin{array}{l}\text { Richard Locke } \\
\text { Thomas Kochan } \\
\text { Monica Romis } \\
\text { Fei Oin }\end{array}$ & $\begin{array}{l}\text { Beyond Corporate Codes of Conduct: Work } \\
\text { Organization and Labour Standards at } \\
\text { Nike's Suppliers }\end{array}$ & 2007 \\
\hline$[02]$ & Bin Jiang & $\begin{array}{l}\text { The Effects of Interorganizational Gover- } \\
\text { nance on Supplier's Compliance with SCC: } \\
\text { An Empirical Examination of Compliant } \\
\text { and Non-compliant Suppliers }\end{array}$ & 2009 \\
\hline$[10]$ & Bin Jiang & $\begin{array}{l}\text { Implementing Supplier Codes of Conduct } \\
\text { in Global Supply Chains: Process Expla- } \\
\text { nations from Theoretic and Empirical } \\
\text { Perspectives }\end{array}$ & 2009 \\
\hline$[15]$ & $\begin{array}{l}\text { Josef Oehmen } \\
\text { Mikko De Nardo } \\
\text { Paul Schönsleben } \\
\text { Roman Boutellier }\end{array}$ & $\begin{array}{l}\text { Supplier Code of Conduct-state-of-the-art } \\
\text { and Customisation in the Electronics } \\
\text { Industry }\end{array}$ & 2010 \\
\hline
\end{tabular}


Table 2. cd.

\begin{tabular}{|c|c|c|c|}
\hline $\begin{array}{c}\text { Reference } \\
\text { number }\end{array}$ & Author(s) & Title & Year \\
\hline$[17]$ & $\begin{array}{l}\text { Rainy X.A. Lu } \\
\text { Peter K.C. Lee } \\
\text { T.C.E. Cheng }\end{array}$ & $\begin{array}{l}\text { Socially Responsible Supplier Development: } \\
\text { Construct Development and Measurement } \\
\text { Validation }\end{array}$ & 2012 \\
\hline [19] & $\begin{array}{l}\text { Mohamad Zakaria } \\
\text { Zanda Garanča } \\
\text { Abdallah Sobeih }\end{array}$ & $\begin{array}{l}\text { Cultural and Legal Challenges in Imple- } \\
\text { menting Code of Conduct in Supply Chain } \\
\text { Management of Mobile Phone Industries: } \\
\text { Sony Ericsson Case Study }\end{array}$ & 2012 \\
\hline$[20]$ & Andrew Herman & $\begin{array}{l}\text { Reassessing the Role of Supplier Codes of } \\
\text { Conduct: Closing the Gap Between Aspira- } \\
\text { tions and Reality }\end{array}$ & 2012 \\
\hline$[03]$ & $\begin{array}{l}\text { Niklas Egels- } \\
\text {-Zandén }\end{array}$ & $\begin{array}{l}\text { Revisiting Supplier Compliance with MNC } \\
\text { Codes of Conduct: Recoupling Policy and } \\
\text { Practice at Chinese Toy Suppliers }\end{array}$ & 2013 \\
\hline$[14]$ & $\begin{array}{l}\text { Martin C. Schleper } \\
\text { Christian Busse }\end{array}$ & $\begin{array}{l}\text { Toward a Standardized Supplier Code of } \\
\text { Ethics: Development of a Design Concept } \\
\text { Based on Diffusion of Innovation Theory }\end{array}$ & 2013 \\
\hline$[01]$ & $\begin{array}{l}\text { Simone Guercini } \\
\text { Antonella La Rocca } \\
\text { Andrea Runfola } \\
\text { Ivan Snehota }\end{array}$ & $\begin{array}{l}\text { Heuristics in Customer-supplier Interac- } \\
\text { tion }\end{array}$ & 2015 \\
\hline$[16]$ & $\begin{array}{l}\text { Tsai Chi Kuo } \\
\text { Chia-Wei Hsu } \\
\text { Jie-Ying Li }\end{array}$ & $\begin{array}{l}\text { Developing a Green Supplier Selection } \\
\text { Model by Using the DANP with VIKOR }\end{array}$ & 2015 \\
\hline [18] & $\begin{array}{l}\text { Sven Helin } \\
\text { Maira Babri }\end{array}$ & $\begin{array}{l}\text { Travelling with a Code of Ethics: A Contex- } \\
\text { tual Study of a Swedish MNC Auditing a } \\
\text { Chinese Supplier }\end{array}$ & 2015 \\
\hline$[12]$ & $\begin{array}{l}\text { Ulla Normann } \\
\text { Chris Ellegaard } \\
\text { Morten Munkgaard } \\
\text { Møller }\end{array}$ & $\begin{array}{l}\text { Supplier Perceptions of Distributive Justice } \\
\text { in Sustainable Apparel Sourcing }\end{array}$ & 2017 \\
\hline$[04]$ & Maciej Urbaniak & $\begin{array}{l}\text { Social Responsibility as a Criterion For Ini- } \\
\text { tial And Periodic Assessment of Suppliers }\end{array}$ & 2018 \\
\hline$[13]$ & $\begin{array}{l}\text { Richard M. Kash- } \\
\text { manian } \\
\text { Environ Qual } \\
\text { Manage }\end{array}$ & $\begin{array}{l}\text { Supplier Codes of Conduct: Company Au- } \\
\text { thorization of Subcontractors }\end{array}$ & 2018 \\
\hline
\end{tabular}

Source: own study. 


\section{OCCURRENCE OF SUPPLIERS CODE OF CONDUCT IN PUBLICATIONS}

The next step in carried out research was an analysis of the number of publications in the respective years (Figure 1).

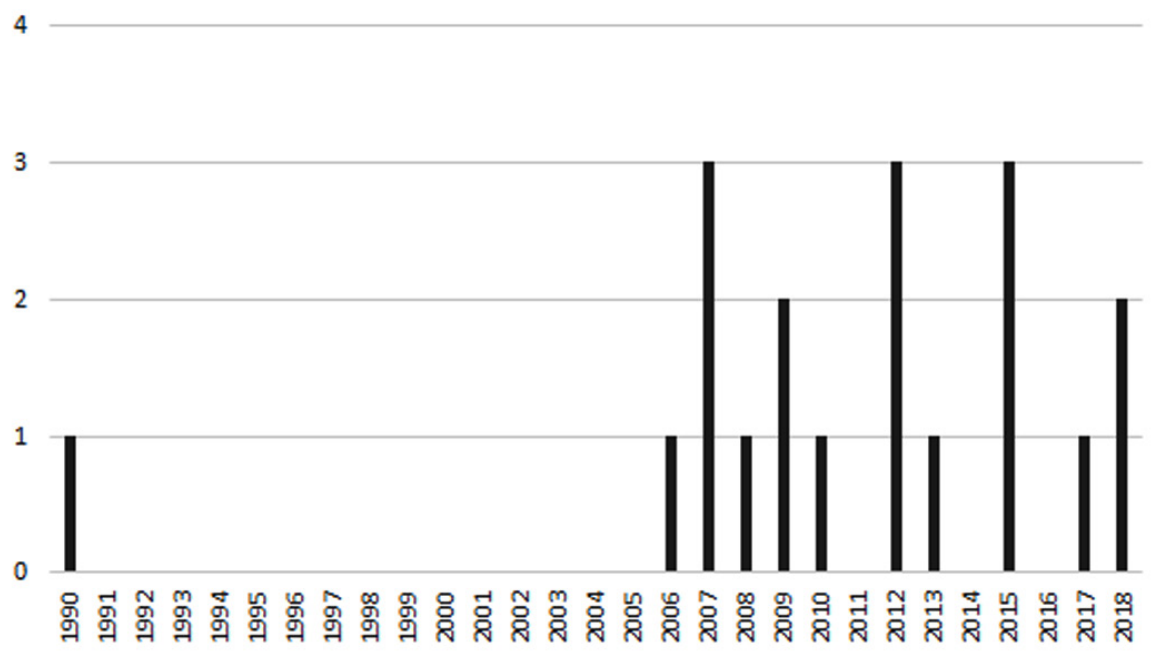

Figure 1. Number of publications in the respective years Source: own study.

Due to the relatively small number of publications qualified for analysis it can be concluded that the subject of supplier code of conduct, despite its presence in scientific publications, has not been widely explored, yet. The first publication appeared in 1990 followed by a break and only in 2006 does the next one appear. The breakdown typical for a life cycle is absent; there is neither birth, nor growth, maturity or decline of the researched subject. Relatively constant number of publications from 2006 (ranging from 1 to 4 per year) allows to qualify the subject in question to "crawling" category, demonstrating neither growing nor falling trends.

In the next stage of proceedings titles of journals publishing selected papers were identified (Figure 2). 


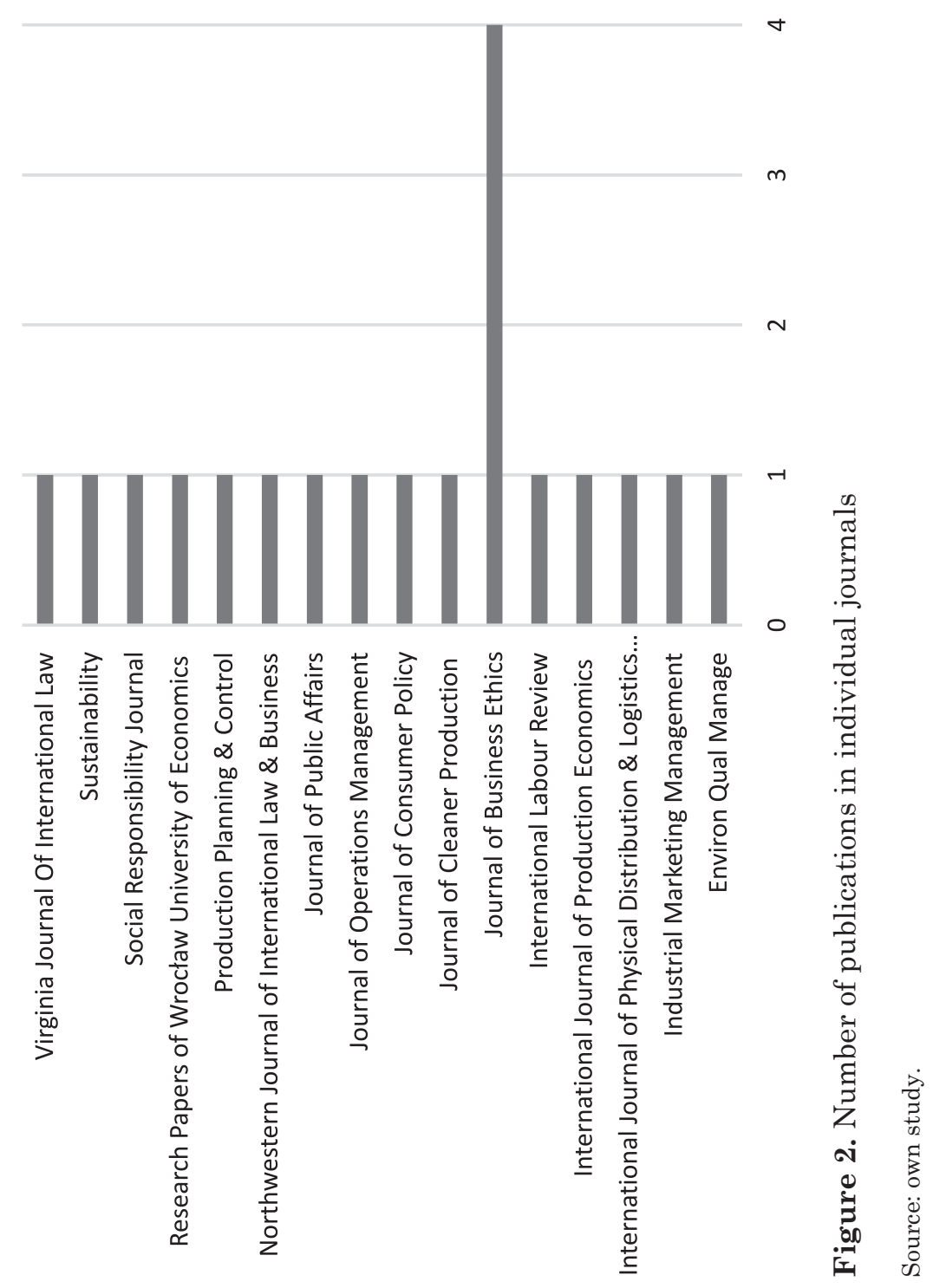


Journal of Business Ethics published the biggest number of articles which does not come as a surprise because of connection between supplier code of conduct with CSR. What is more, also Social Responsibility Journal, Sustainability and Environ Qual Manage can be included in this research area.

Additionally, it can be noticed that the subject of supplier code of conduct occurs in journals dedicated to law (Virginia Journal Of International Law and Northwestern Journal of International Law \& Business), marketing and logistics (Industrial Marketing Management, International Journal of Physical Distribution \& Logistics Management), management (Journal of Operations Management, Research Papers of Wroclaw University of Economics), production (International Journal of Production Economics, Journal of Cleaner Production, Production Planning \& Control).

\section{KEYWORDS ANALYSIS}

Importance of publications in scientific journals for disseminating knowledge seems indisputable. In bibliometric studies, keywords of publications are regarded as the fundamental element of presented research area (Su \& Lee, 2010). Thus, they should best describe the subject matter of publications and refer to key terms, ideas or scientific content in a concise manner (Ding et al., 2001).

Keyword analysis, as a kind of quantitative content analysis, has been used to identify relevant topics in different research fields (Kevork \& Vrechopoulos 2008). The analysis carried out led to identification of research areas within which the subject of supplier code of conduct was handled. Table 3 presents singled out research fields together with keywords used to identify them along with reference numbers of journals.

The analysis covered 55 keywords which were later grouped into 12 subject areas: 1 . Codes, 2. CSR, 3. International management, 4. Labour, 5. Method, 6. Relationship management, 7. Risk, 8. Sector, 9. Selection, assessment and development, 10. Entities, 11. Supply chain, and 12. Transaction cost.

An overview of keywords demonstrates that the studied subject most frequently is connected to the issue of suppliers (it appeared eight times as a keyword) and Corporate Social Responsibility (CSR 
as a keyword appeared seven times). Relatively often the term "code of conduct" occurred which shows its direct reference to the studied notion. Further on, "supply chain management" appears (four times).

Table 3. The key areas of research on the supplier code of conduct

\begin{tabular}{|c|c|c|}
\hline $\begin{array}{c}\text { Key research } \\
\text { areas }\end{array}$ & Keywords & Publications \\
\hline Codes & $\begin{array}{l}\text { - Code of Conduct of the Elec- } \\
\text { tronic Industry Citizenship } \\
\text { Coalition (EICC) } \\
\text { - Code of ethics } \\
\text { - Codes of conduct } \\
\text { - Regulation } \\
\text { - Supplier codes of conduct }\end{array}$ & $\begin{array}{l}{[16]} \\
{[14],[18]} \\
{[03],[07],[08],[12],[19]} \\
{[02]} \\
{[10],[13],[15]}\end{array}$ \\
\hline CSR & $\begin{array}{l}\text { - } \text { CSR } \\
\text { - Distributive justice } \\
\text { - Environmental performance } \\
\text { - Supply chain sustainability } \\
\text { - Supply chain transparency } \\
\text { - Sustainable sourcing }\end{array}$ & $\begin{array}{l}\text { [04], [07], [08], [14], [15], [17], [19] } \\
{[12]} \\
{[16]} \\
{[13]} \\
{[13]} \\
{[12]}\end{array}$ \\
\hline $\begin{array}{l}\text { International } \\
\text { management }\end{array}$ & $\begin{array}{l}\text { - } \text { China } \\
\text { - Global operations } \\
\text { - Globalization } \\
\text { - Multinational companies } \\
\text { - Multinational corporations }\end{array}$ & $\begin{array}{l}{[03],[07],[08]} \\
{[02]} \\
{[18]} \\
{[19]} \\
{[07]}\end{array}$ \\
\hline Labour & $\begin{array}{l}\text { - Labour standards } \\
\text { - Labour practice } \\
\text { - Wages } \\
\text { - Workers' rights }\end{array}$ & $\begin{array}{l}{[08]} \\
{[03],[07]} \\
{[08]} \\
{[03]}\end{array}$ \\
\hline Method & $\begin{array}{l}\text { - Analytic Network Process } \\
\text { (ANP), (DANP) } \\
\text { - Content analysis } \\
\text { - Multi-method research } \\
\text { - } \text { Qualitative study } \\
\text { - Structural equation model } \\
\text { - Survey }\end{array}$ & $\begin{array}{l}{[16]} \\
{[14]} \\
{[14]} \\
{[12]} \\
{[10]} \\
{[17]}\end{array}$ \\
\hline $\begin{array}{l}\text { Relationship } \\
\text { management }\end{array}$ & $\begin{array}{l}\text { - Customer-supplier relationships } \\
\text { - Interaction } \\
\text { - Mediating process } \\
\text { - Supplier relations } \\
\text { - Supplier relationship } \\
\text { - Trade union }\end{array}$ & $\begin{array}{l}{[01]} \\
{[01]} \\
{[10]} \\
{[07]} \\
{[03]} \\
{[08]}\end{array}$ \\
\hline Risk & - Risk management & [15] \\
\hline
\end{tabular}


Table 3. cd.

\begin{tabular}{|c|c|c|}
\hline $\begin{array}{c}\text { Key research } \\
\text { areas }\end{array}$ & Keywords & Publications \\
\hline Sector & $\begin{array}{l}\text { - Apparel industry } \\
\text { - Athletic footwear industry } \\
\text { - Mobile technology } \\
\text { - Reebok } \\
\text { - Toy industry }\end{array}$ & $\begin{array}{l}{[12]} \\
{[08]} \\
{[19]} \\
{[08]} \\
{[03],[07]}\end{array}$ \\
\hline $\begin{array}{l}\text { Selection, } \\
\text { assessment } \\
\text { and develop- } \\
\text { ment }\end{array}$ & $\begin{array}{l}\text { - Assessment governance } \\
\text { - Monitoring } \\
\text { - Prior approval/authorization of } \\
\text { use of subcontractors } \\
\text { - Scale development and valida- } \\
\text { tion } \\
\text { - Supplier assessment } \\
\text { - Supplier development } \\
\text { - Supplier selection }\end{array}$ & $\begin{array}{l}{[12]} \\
{[19]} \\
{[13]} \\
{[17]} \\
{[04]} \\
{[17]} \\
{[16]}\end{array}$ \\
\hline Entities & $\begin{array}{l}\text { - Actors in business relationships } \\
\text { - Subcontractors } \\
\text { - Suppliers }\end{array}$ & $\begin{array}{l}{[01]} \\
{[13]} \\
{[03],[04],[07],[10],[13],[15],[16]} \\
{[17]}\end{array}$ \\
\hline Supply chain & $\begin{array}{l}\text { - Supply chain management } \\
\text { - Supply chain sustainability } \\
\text { - Supply chain transparency } \\
\text { - Supply management }\end{array}$ & $\begin{array}{l}{[04],[15],[18],[19]} \\
{[13]} \\
{[13]} \\
{[02]}\end{array}$ \\
\hline $\begin{array}{l}\text { Transaction } \\
\text { cost }\end{array}$ & $\begin{array}{l}\text { - Interorganizational governance } \\
\text { - Organisational behaviour } \\
\text { - Transaction cost economics }\end{array}$ & $\begin{array}{l}{[10]} \\
{[02]} \\
{[18]}\end{array}$ \\
\hline
\end{tabular}

Source: own study.

With reference to the number of publications in individual research areas, it can be noticed that most of them concerns the following fields: odes (12 publications), CSR (12 publications), and Entities (10 publications). Other well represented subject areas are: International Management, Selection, Assessment and Development, Supply Chain (seven publications each), Method, Relationship Management, and Sector (six publications each). The least represented is the subject of Labour (five publications), Transaction Cost (three publications) and Risk (one publication). 


\section{DISCUSSION}

The analysed publications show that the subject of supplier code of conduct refers to many research areas and is a subject of multifaceted analysis. Carried out bibliometric analysis of reviewed scientific publications and contextual analysis led to formulation of answers to the research questions raised.

A relatively small number of the reviewed scientific publications on supplier code of conduct, present in selected databases (20) and time of their publication indicate that it is a constant and moderate subject of interest for researchers. Consequently, there is a research gap in this field justified also by the importance of cooperation with suppliers for a contemporary organization.

The analysed publications appeared in different scientific journals, mostly related to management and, marginally, to legal issues. In the course of the research it was proven that the subject of supplier code of conduct is set in various and numerous research areas. This proves its large research potential. It seems quite obvious to attribute supplier code of conduct to different guidelines, standards, regulations, and codes where it serves as one of examples. It results from specifics of the tool itself, which is a set of systematised guidelines for suppliers on how they should operate. Since this type of codes are usually not obligatory, they are regarded as a CSR tool. For many international organisations, despite a lack of formal and legal requirements, using suppliers code of conduct is expected by international groups of stakeholders.

Supplier codes of conduct are related to the choice, selection, and development of suppliers. Their implementation and compliance may be a condition for establishing and maintaining cooperation between organisations. The presence of supplier codes of conduct in supply chain management proves the complexity of this concept and for participants of supply chains also other aspects, apart from cost related requirements, play an important role. One can also indicate probability of change in the value of transactional costs incurred which may result from the increase of trust towards suppliers with an implemented supplier code of conduct.

The studied publications distinguish among entities interested in suppliers codes of conduct not only suppliers and subcontractors, whom 
the analysed tool directly concerns, but also other business players without detailed indication of type of entities. This might show that interest in codes has a very broad scope.

The analysed subject is handled in the context of international markets, in particular the countries (China) where problems related to globalisation, such as child labour, exploitation of employees, and poverty wages, focus. This problem concerns to the greatest extent international corporations which are consequently included in researchers' areas of interest. The escalation of these problems is substantially conditioned by the type of sector where it occurred; clothing, toy, and mobile sector.

\section{CONCLUSIONS}

The carried-out research proved the existence of a research gap in scientific penetration of the subject of supplier code of conduct. The small number of peer reviewed publications on this subject is the most convincing proof. Calls for reducing the proven gap may concern both increasing the number of publications and demonstrating further, promising research directions.

Among others, the following valuable directions for future research on supplier code of conduct can be indicated:

- $\quad$ study on actual motifs of individual organisations for following codes of conduct and learning opinions on achieved results,

- analysis of accessibility of professional advisory services on designing and implementation of supplier code of conduct,

- analysis of content and structure of supplier code of conduct used by organisations and learning about the changes occurring with time and experience,

- analysis of roles and functions attributed to supplier code of conduct taking into account regional, sectoral and individual specifics (organisational level),

- $\quad$ analysis of the need to standardise supplier code of conduct by potential creating norms as a reference model of proceedings. 


\section{REFERENCES}

Bai, C. \& Sarkis, J. (2010). Integrating sustainability into supplier selection with grey system and rough set methodologies. International Journal of Production Economics, 124(1), 252-264.

Barrientos, S. \& Smith, S. (2007). Do workers benefit from ethical trade? Assessing codes of labour practice in global production systems. Third World Quarterly, 28(4), 713-729.

Burgess, K., Singh, P.J. \& Koroglu, R. (2006). Supply chain management: A structured literature review and implications for future research. International Journal of Operations \& Production Management, 26(7), 703-729.

Chan, A. \& Siu, K. (2010). Analysing exploitation: The mechanisms underpinning low wages and excessive overtime in Chinese export factories. Critical Asian Studies, 42(2), 167-190.

Czakon, W. (2016). Metodyka systematycznego przeglądu literatury. In: W. Czakon (ed.). Podstawy metodologii badań w naukach o zarzadzaniu (pp. 124-139). Warszawa: Wydawnictwo Nieoczywiste.

Diller, J. (1999). A social conscience in the global marketplace? Labour dimensions of codes of conduct, social labelling and investor initiatives. International Labour Review, 138(2), 99-129.

Ding, Y., Chowdhury, G.G. \& Foo, S. (2001). Bibliometric cartography of information retrieval research by using co-word analysis. Information Processing and Management, 37(6), 817-842.

Egels-Zandén, N. \& Hyllman, P. (2007). Evaluating strategies for negotiating workers' rights in transnational corporations: The effects of codes of conduct and global agreements on workplace democracy. Journal of Business Ethics, 76, 207-223.

Egels-Zandén, N. (2007). Suppliers compliance with MNCs codes of conduct: Behind the scenes at Chinese toy suppliers. Journal of Business Ethics, $75,46-62$.

Egels-Zandén, N. (2013). Revisiting supplier compliance with MNC codes of conduct: Recoupling policy and practice at Chinese toy suppliers. Journal of Business Ethics, 119, 59-75.

Guercini, S., La Rocca, A., Runfola, A. \& Snehota, I. (2015). Heuristics in customer - supplier interaction. Industrial Marketing Management, 48, 26-37.

Helin, S. \& Babri, M. (2015). Travelling with a code of ethics: A contextual study of a Swedish MNC auditing a Chinese supplier. Journal of Cleaner Production, 107, 41-53. 
Herman, A. (2012). Reassessing the role of supplier codes of conduct: Closing the gap between aspirations and reality. Virginia Journal of International Law, 52, 445-482.

Huyse, L. \& Parmentier, S. (1990). The dialogue between consumers and suppliers through codes of conduct in the European community. Journal of Consumer Policy, 13, 253-272.

Jenkins, R. (2005). Globalization, corporate social responsibility and poverty. International Affairs, 81(3), 525-540.

Jiang, B. (2009a). Implementing supplier codes of conduct in global supply chains: Process explanations from theoretic and empirical perspectives. Journal of Business Ethics, 85, 77-92.

Jiang, B. (2009b). The effects of interorganizational governance on supplier's compliance with SCC: An empirical examination of compliant and non-compliant suppliers. Journal of Operations Management, 27(4), 267-280.

Kashmanian, R.M. (2018). Supplier codes of conduct: Company authorization of subcontractors. Environmental Quality Management, 27, 9-27.

Kenny, K.E. (2007). Code or contract: Whether Wal-Mart's code of conduct creates a contractual obligation between Wal-Mart and the employees of its foreign suppliers. Northwestern Journal of International Law \& Business, 27, 453-473.

Kevork, E.K. \& Vrechopoulos, A.P. (2008). CRM Literature: Conceptual and functional insights by keyword analysis. Marketing Intelligence and Planning, 27(1), 48-85.

Kolk, A. \& van Tulder, R. (2002b). The effectiveness of self-regulation: Corporate codes of conduct and child labour. European Management Journal, 20(3), 260-271.

Kolk, A. \& van Tulder, R. (2002a). Child labor and multinational conduct: A comparison of international business and stakeholder codes. Journal of Business Ethics, 36, 291-301.

Kumara, D. \& Rahman, Z. (2015). Sustainability adoption through buyer supplier relationship across supply chain: A literature review and conceptual framework. International Strategic Management Review, 3, 110-127.

Kuo, T.Ch., Hsu, Jie-Ying, Ch.-W. \& Li, J.-Y. (2015). Developing a green supplier selection model by using the DANP with VIKOR. Sustainability, 7(2), 1661-1689.

Locke, R., Kochan, T., Romis, M. \& Qin, F. (2007). Beyond corporate codes of conduct: Work organization and labour standards at Nike's suppliers. International Labour Review, 146(1-2), 21-37.

Lu, R.X.A., Lee, P.K.C. \& Cheng, T.C.E. (2012). Socially responsible supplier development: Construct development and measurement validation. International Journal of Production Economics, 140(1), 160-167. 
Mazur, Z. \& Orłowska, A. (2018). Jak zaplanować i przeprowadzić systematyczny przegląd literatury. Polskie Forum Psychologiczne, 23(2), 235-236.

Normann, U., Ellegaard, Ch. \& Møller, M.M. (2017). Supplier perceptions of distributive justice in sustainable apparel sourcing. International Journal of Physical Distribution \& Logistics Management, 47(5), 368-386.

Oehmen, J., De Nardo, M., Schönsleben, P. \& Boutellier, R. (2010). Supplier code of conduct-state-of-the-art and customisation in the electronics industry. Production Planning \& Control, 21(7), 664-679.

Orłowska, A., Mazur, Z. \& Łaguna, M. (2017). Systematyczny przegląd literatury: na czym polega i czym różni się od innych przeglądów. Ogrody Nauk i Sztuk, 7, 350-363.

Pedersen, E.R. \& Andersen, M. (2006). Safeguarding corporate social responsibility (CSR) in global supply chains: How codes of conduct are managed in buyer-supplier relationships. Journal of Public Affairs, 6(3/4), 228-240.

Petticrew, M. \& Roberts, H. (2006). Systematic Reviews in the Social Sciences: A Practical Guide. Oxford: Blackwell.

Radin, T.J. (2004). The effectiveness of global codes of conduct: Role models that make sense. Business and Society Review, 109, 415-447.

Roberts, S. (2003). Supply chain specific? Understanding the patchy success of ethical sourcing initiatives. Journal of Business Ethics, 44(2/3), 159-170.

Rowley, J. \& Slack, F. (2004). Conducting a literature review. Manage Research News, 27(6), 31-39.

Schleper, M.C. \& Busse, Ch. (2013). Toward a standardized supplier code of ethics: Development of a design concept based on diffusion of innovation theory. Logistics Research, 6(4), 187-216.

Schwartz, M. (2001). The nature of the relationship between corporate codes of ethics and behaviour. Journal of Business Ethics, 32, 247-262.

Sethi, S.P. (2002). Standards for corporate conduct in the international arena: Challenges and opportunities for multinational corporations. Business and Society Review, 107, 20-40.

Seuring, S. \& Müller, M. (2008). From a literature review to a conceptual framework for sustainable supply chain management. Journal of Cleaner Production, 16, 1699-1710.

Su, H.N. \& Lee, P.C. (2010). Mapping knowledge structure by keyword co-occurrence: A first look at journal papers in technology foresight. Scientometrics, 85(1), $65-79$.

Tranfield, D., Denyer, D. \& Smart, P. (2003). Towards a methodology for developing evidence-informed management knowledge by means of systematic review. British Journal of Management, 14, 207-222. 
Urbaniak, M. (2018). Social responsibility as a criterion for initial and periodic assessment of supplier. Research Papers of Wroctaw University of Economics, $505,66-78$.

Waddock, S., Bodwell, C.B. \& Graves, S. (2002). Responsibility: The new business imperative. Academy of Management Executive, 16(2), 132-148.

$\mathrm{Yu}, \mathrm{X}$. (2008). Impacts of corporate code of conduct on labor standards: A case study of Reebok's athletic footwear supplier factory in China. Journal of Business Ethics, 81, 513-529.

Zakaria, M., Garanča, Z. \& Sobeih, A. (2012). Cultural and legal challenges in implementing code of conduct in supply chain management of mobile phone industries: Sony Ericsson case study. Social Responsibility Journal, 8(2), 227-241. 


\title{
KODEKS POSTĘPOWANIA DOSTAWCÓW: SYSTEMATYCZNY PRZEGLĄD LITERATURY
}

\begin{abstract}
Abstrakt
Tło badań. Współpraca z dostawcami ma obecnie istotne znaczenie dla zdolności organizacji do realizacji celów. Procesy wyłaniania dostawców uwzględniają różnorodne kryteria, które coraz częściej nie mają wyłącznie ekonomicznego charakteru. Kodeks postępowania dostawców jest jednym z takich narzędzi kształtowania relacji pomiędzy organizacjami i ich dostawcami, które stosowane głównie na rynkach międzynarodowych, rozszerza wymiary wymagań, jakie powinni spełniać dostawcy. W artykule dokonuje się analizy stopnia i zakresu obecności problematyki kodeksów postępowania dostawców w recenzowanych publikacjach naukowych.
\end{abstract}

Cel badań. Celem badań jest identyfikacja obecności problematyki kodeksów postępowania dostawców w recenzowanych czasopismach naukowych. Postawiono następujące pytania badawcze: 1 . czy istnieje luka badawcza w zakresie problematyki kodeksu postępowania dostawców?, 2. w których czasopismach naukowych publikuje się artykuły poświęcone problematyce kodeksu postępowania dostawców?, 3. w jakich obszarach badawczych podejmowana jest problematyka kodeksu postępowania dostawców?

Metodologia. Podstawową metodą badawczą był systematyczny przegląd literatury. Doboru tekstów poddanych analizie dokonano na podstawie bazy EBSCO and ProQuest.

Kluczowe wnioski. Analiza bibliometryczna oraz kontekstowa pozwoliły sformułować następujace wnioski: 1. problematyka kodeksu postępowania dostawców jest obecna w recenzowanych publikacjach naukowych w stopniu bardzo umiarkowanym; 2. czasopisma naukowe, w których opublikowano artykuły na temat kodeksu postępowania dostawców mają zróżnicowany profil; 3. kodeks postępowania dostawców stanowi przedmiot badań w licznych obszarach badawczych. W następstwie systematycznego przeglądu literatury sformułowano ponadto propozycje przyszłych kierunków badań.

Słowa kluczowe: dostawcy, kodeks postępowania dostawców, systematyczny przegląd literatury. 